\section{Carbon and Nitrogen Budgets in Spring and Fall Tomato Crops}

\author{
Peter C. Andersen, Fred M. Rhoads, Steven M. Olson, and Kristen D. Hill \\ University of Florida, North Florida Research and Education Center-Quincy, \\ Route 3, Box 4370, Quincy, FL 32351-9529 \\ Additional index words. Lycopersicon esculentum, carbon efficiency, nitrogen efficiency, \\ yield, yield efficiency
}

Abstract. Carbon and nitrogen budgets were determined for 'Colonial' (spring) and 'Equinox' (fall) tomato (Lycopersicon esculentum Mill.) plants grown on raised beds with black polyethylene mulch and supplied with preplant-N at $0,67,134,202$, or $269 \mathrm{~kg} \cdot \mathrm{ha}^{-1}$. For both spring and fall experiments, we quantified the partitioning of dry matter, $\mathbf{N}$, and $\mathrm{C}$, and determined marketable and total yield. In the spring study, the concentration of $\mathrm{N}$ in leaves, stems, and in total plants increased linearly with level of $\mathbf{N}$ fertilization, whereas a quadratic relationship described the amount of $\mathrm{N}$ contained in the fruit (maximum with $\left.202 \mathrm{~kg} \cdot \mathrm{ha}^{-1}\right)$. Quadratic relationships occurred between rate of fertilization and leaf weight, stem weight, total plant weight, marketable yield, and total yield in the spring study, with maximum values at 134 or $202 \mathrm{~kg} \cdot \mathrm{ha}^{-1}$ rates of $\mathrm{N}$ fertilization. In the fall crop, fewer significant relationships occurred between dependent variables and rate of $N$ fertilization, and coefficients of determination tended to be much lower than in the spring study. The fraction of $\mathrm{N}$ in leaves, stems, and roots (fall study only) was influenced by $\mathrm{N}$ fertilization. Effects of $\mathrm{N}$ fertilization on the fraction of $\mathrm{C}$ partitioned to any plant part was either nonsignificant or significant at $P=0.05$. Total yield was related to $N$ fertilization in a quadratic manner, but marketable yield was significantly affected only in the spring study. In both studies, increasing the rate of $N$ fertilization reduced the $C: N$ linearly for all tissues. In all cases, the quantity of $\mathrm{N}$ partitioned to vegetative tissue was at least $65 \%$ of that partitioned to the fruit, and the quantity of $\mathrm{C}$ in the plant was at least $74 \%$ of that in the fruit. In conclusion, although $\mathrm{N}$ fertilization above $202 \mathrm{~kg} \cdot \mathrm{ha}^{-1}$ generally increased the concentration and total amount of $\mathrm{N}$ in vegetative tissues, it did not increase yield. Also, the highest rate of $\mathrm{N}$ fertilization $\left(269 \mathrm{~kg} \cdot \mathrm{ha}^{-1}\right)$ resulted in a much lower efficiency of applied $\mathbf{N}$ [defined as: ( $\mathbf{N}$ plant $+\mathbf{N}$ fruit)/ $\mathbf{N}$ applied], and a much higher level of residual soil nitrate-N.

Predictive models concerning crop response to fertilizer and to soil $\mathrm{N}$ have normally considered yield maximization with little consideration for nonharvested plant tissues or the environment (Angus, 1995). From an economic perspective, yield output as a function of fertilization has often been described by curvilinear relationships of diminishing returns. The cost of fertilizer and other inputs are balanced against the expected price of the crop and the utilization of inputs is often determined on that basis. The relatively low price of synthetic nitrogen fertilizers relative to total agricultural inputs has traditionally resulted in excessive application. Thus, during the last decade the overriding issue concerning fertilizer use has been the environmental consequences of the leaching/runoff of nitrate and other pollutants to ground and surface water (Strong, 1995).

Nitrogen is a significant input for tomato production in the southeastern United States,

Received for publication 21 Aug. 1998. Accepted for publication 9 Dec.1998. Florida Agricultural Experiment Station Journal Series No. R-06471. The cost of publishing this paper was defrayed in part by the payment of page charges. Under postal regulations, this paper therefore must be hereby marked advertisement solely to indicate this fact. and is often a factor limiting tomato production (Everett, 1976; Locascio et al., 1997; Rhoads et al., 1996). In Florida, the recommended rate of $\mathrm{N}$ fertilization for tomatoes is $196 \mathrm{~kg} \cdot \mathrm{ha}^{-1}$ (Hochmuth and Hanlon, 1995; Hochmuth and Maynard, 1996), although commercial growers apply up to $560 \mathrm{~kg} \cdot \mathrm{ha}^{-1}$, and $400 \mathrm{~kg} \cdot \mathrm{ha}^{-1}$ is common (Everett, 1976; Rhoads et al., 1996). Both the entire plant plus harvested fruit may be significant reservoirs of $\mathrm{N}$, and total $\mathrm{N}$ uptake will depend heavily on the quantities partitioned into both components (Stark et al., 1983). Drinkwater et al. (1995), in a study involving conventional and organic cropping systems of tomatoes, showed that soil fertility levels influenced $\mathrm{C}$ and $\mathrm{N}$ dynamics and had a great impact on plant-pathogen and plant-herbivore interactions; however, partitioning of $\mathrm{C}$ and $\mathrm{N}$ was not emphasized in that study. Knowledge of the impact of fertilization on yield and quality is important from a production standpoint. Also important from a plant growth perspective are the quantities of $\mathrm{N}$ and $\mathrm{C}$ partitioned to each plant tissue, and from an environmental perspective, the extent to which the soil is enriched or depleted of $\mathrm{N}$.

One measure of fertilizer efficiency is to quantify fertilizer-N recovered in the harvested crop in comparison with that applied (Stark et al., 1983; Strong, 1995). Several investigators have shown that the percentage of $\mathrm{N}$ recovered, measured by the difference between ${ }^{15} \mathrm{~N}$ - fertilizer applied and that in the crop and crop residue, varies between $10 \%$ and $80 \%$ (Strong, 1995). The lowest efficiencies ( $<20 \%$ of $\mathrm{N}$ recovery) were due to climatic extremes, or poor method or timing of $\mathrm{N}$ application. De Willigen et al. (1992) reported that, at the end of the growth period in soils of northwest Europe, the minimum quantity of residual nitrate-N after application of recommended rates of $\mathrm{N}$ was $4,9,13,25,27$, and $116 \mathrm{~kg} \cdot \mathrm{ha}^{-1}$, respectively, for winter wheat (Triticum aestivum L.), sugar beet (Beta vulgaris L.), potato (Solanum tuberosum L.), leek (Allium ampeloprasum Tausch.), brussel sprouts (Brassica oleracea L. var. Gemmifera), and spinach (Spinacia oleracae L.). In addition, the mineralization of soil organic $\mathrm{N}$ can result in the release of 50 to $100 \mathrm{~kg} \cdot \mathrm{ha}^{-1}$ of nitrate during the growing season (Neeteson, 1995).

In this study, our objectives were to test the influence of rate of $\mathrm{N}$ fertilization on: 1) the fraction and total amount of dry matter, $\mathrm{N}$, and $\mathrm{C}$ partitioned to various tomato plant tissues; 2) marketable and total fruit yield; and 3) residual soil $\mathrm{N}$ levels after final harvest.

\section{Materials and Methods}

For the spring study, 'Colonial' tomato plants were transplanted 29 Mar. 1996, utilizing a black polyethylene mulch planting system with raised beds $0.91 \mathrm{~m}$ wide and $1.83 \mathrm{~m}$ apart at the North Florida Research and Education Center (NFREC), Quincy. Prior to transplanting, the raised beds were treated with 98\% methyl bromide- $2 \%$ chloropicrin (trichloromethane) at $225 \mathrm{~kg} \cdot \mathrm{ha}^{-1}$. Plant density was 10,760 plants/ha. Tomato transplants were obtained from $3.8 \times 3.8 \times 6.4 \mathrm{~cm}$ deep (pyramidal; $30.8 \mathrm{~cm}^{3}$ ) volumes of Terra-Lite (ScottSierra Horticultural Products Co., Marysville, Ohio) media. Preplant N (ammonium nitrate) was applied at one of five rates $(0,67,134$, 202 , or $269 \mathrm{~kg} \cdot \mathrm{ha}^{-1}$ ) in a 1.33 -m-wide area that was used as the raised bed just prior to the time of bed formation. Soil type was an Orangeburg loamy fine sand (Typic Paleudult: Silaceous Thermic). All treatments received triple superphosphate $(0-46-0)$ at $224 \mathrm{~kg} \cdot \mathrm{ha}^{-1}$ and $\mathrm{K}_{2} \mathrm{SO}_{4}(0-0-50)$ at $336 \mathrm{~kg} \cdot \mathrm{ha}^{-1}$. Plants received drip irrigation with emitters spaced 0.3 $\mathrm{m}$ apart. Each single-row plot contained 18 plants spaced $0.51 \mathrm{~m}$ apart, and only the 12 center plants were harvested for yield. Wooden stakes and twine were used to retain plants in an upright position. Standard insecticide and fungicide applications were employed (Hochmuth and Maynard, 1996). Tomatoes were harvested on 20 June, 26 June, and 8 July, and were graded into medium, large, and extra-large fruit and culls. Total yield included all graded tomatoes including culls, while marketable yield did not include culls.

For the fall study, 'Equinox' tomatoes were planted 31 July 1997 at the NFREC-Quincy. The only difference in the culture of 'Equinox' in late summer and fall compared with 'Colonial' in the spring was that white on black polyethylene mulch was used for 'Equinox'. Harvest dates were 13, 22, and 30 Oct. 1997.

Vegetative plant material was harvested 27 
June 1996 and 31 Oct. 1997, respectively, for the spring and fall experiments. Plant weight designations refer to vegetative tissue (leaves, roots, and stems), while total weight refers to plant weight plus fruit weight. The same holds for the weight of $\mathrm{C}$ and $\mathrm{N}$. Three plants from each of 20 plots were severed at the ground level, cut into $0.30-\mathrm{m}$ pieces, and placed in paper bags. Root systems were excavated by digging holes $0.45 \mathrm{~m}$ wide $\times 0.25 \mathrm{~m}$ deep and washing the root system with water. In addition, root weight outside this region was estimated by collecting root segments located in three random soil core cylinders $5.5 \mathrm{~cm}$ wide $\times 20 \mathrm{~cm}$ deep in each plot. The soil volume in the raised bed under polyethylene mulch to a depth of $0.25 \mathrm{~m}$ deep was estimated and root weight outside the original holes was calculated. Total root weight was estimated by adding root weight in the original hole plus that calculated to exist outside the hole. Harvested plant material was dried at $50{ }^{\circ} \mathrm{C}$ for 4 to $6 \mathrm{~d}$. Stem, leaf, and fruit dry weights were determined and subsamples of stem, leaf, and root tissue from each plant were dried for an additional 7 to $10 \mathrm{~d}$ at $80^{\circ} \mathrm{C}$. Subsamples of tissue were finely ground using a tissue grinder. Concentrations of elemental $\mathrm{C}$ and $\mathrm{N}$ were quantified for each sample. Sample analysis was accomplished with a Perkin Elmer Model 2400 Series II CHNS/O analyzer (Perkin Elmer Corp., Norwalk, Conn.) equipped with an autosampler. Combustion temperature was 925 ${ }^{\circ} \mathrm{C}$. Leaf, stem, and root samples (2-3 mg) from each of three plants were each run in duplicate or triplicate and mean values were calculated. Mean values for each experimental unit were calculated prior to statistical analysis. Fruit $\mathrm{N}$ and $\mathrm{C}$ were determined in an analogous manner, except that samples were collected from each experimental unit rather than from each individual plant.

Residual soil $\mathrm{NO}_{3}^{-}$was determined by the calcium sulfate extraction method (Hanlon et al., 1994) from 0.25-m-deep soil cores under the polyethylene mulch within 1 week after final harvest for the spring and fall experiment. Nitrogen efficiency for each treatment was defined as: (plant $\mathrm{N}+$ fruit $\mathrm{N}$ )/ $\mathrm{N}$ applied.

A randomized block design was used with four blocks. Statistical analyses were via regression (five levels of preplant $\mathrm{N}$ ), using general linear models procedures of the statistical analysis system for all variables (SAS Institute, 1985). In all cases, levels of $\mathrm{N}$ fertilization were treated as the independent vari- able. Linear, quadratic, and cubic relationships were assessed at $P$ values of $0.05,0.01$, 0.001 , and 0.0001 . If an equal level of significance $(P$ value) was obtained for two or more relationships, then a 0.10 or greater increase in $R^{2}$ was used as the determinant to use the next higher order polynomial.

\section{Results and Discussion}

Tissue $N$ and $C$ concentrations. In both spring and fall plantings, the concentration of leaf $\mathrm{N}$ and stem $\mathrm{N}$ increased linearly with rates of preplant $\mathrm{N}$ (Table 1). Leaf $\mathrm{N}$ and stem $\mathrm{N}$ varied from 12.6 to $25.2 \mathrm{~g} \cdot \mathrm{kg}^{-1}$ and 8.7 to 18.6 $\mathrm{g} \cdot \mathrm{kg}^{-1}$, respectively, for the spring planting, and 26.1 to $34.2 \mathrm{~g} \cdot \mathrm{kg}^{-1}$ and 11.4 to $20.0 \mathrm{~g} \cdot \mathrm{kg}^{-1}$, respectively, for the fall planting. The postharvest values of leaf $\mathrm{N}$ are not analogous to 4th to 8th week leaf $\mathrm{N}$ values developed to establish deficiency standards $\left(28 \mathrm{~g} \cdot \mathrm{kg}^{-1}\right)$ (Hochmuth et al., 1991). The substantially higher leaf $\mathrm{N}$ values in the fall than in the spring may have resulted from differences in cultivar and/or climatic conditions. Rates of $\mathrm{N}$ explained only a small percentage of the variation in concentration of $\mathrm{C}$ in leaf and stem tissue in the spring; in the fall their effect was

Table 1. Effects of rate of $\mathrm{N}$ fertilization on concentrations $\left(\mathrm{g} \cdot \mathrm{kg}^{-1}\right)$ of $\mathrm{N}$ and $\mathrm{C}$, and $\mathrm{C}: \mathrm{N}$ ratios in leaves, stems, roots, plants, fruit, and total (plant plus fruit) of two cultivars of tomato planted 29 Mar. 1996 and 31 July 1997.

\begin{tabular}{|c|c|c|c|c|c|c|c|c|}
\hline \multirow[b]{2}{*}{ Tissue element ${ }^{2}$} & \multicolumn{5}{|c|}{$\mathrm{N}$ fertilization $\left(\mathrm{kg} \cdot \mathrm{ha}^{-1}\right)$} & \multicolumn{3}{|c|}{ Statistics } \\
\hline & 0 & 67 & 134 & 202 & 269 & $\mathrm{y}=$ & $R^{2}$ & $P$ \\
\hline \multicolumn{9}{|c|}{ Colonial, 1996} \\
\hline Leaf $\mathrm{N}$ & 12.6 & 17.1 & 21.3 & 23.6 & 25.2 & $13.6+0.047 x$ & 0.72 & $* * * *$ \\
\hline $\mathrm{C}: \mathrm{N}$ ratio & 30.8 & 22.7 & 18.2 & 16.5 & 15.3 & $28.11-0.055 x$ & 0.74 & $* * * *$ \\
\hline Stem N & 8.70 & 10.9 & 13.0 & 15.3 & 18.6 & $8.40+0.036 \mathrm{x}$ & 0.80 & $* * * *$ \\
\hline $\mathrm{C}$ & 422 & 413 & 408 & 412 & 416 & $421-0.16 x+0.00053 x^{2}$ & 0.33 & * \\
\hline $\mathrm{C}: \mathrm{N}$ ratio & 30.6 & 29.5 & 27.9 & 27.8 & 25.1 & $30.7-0.019 x$ & 0.21 & $*$ \\
\hline Plant N & 10.2 & 12.9 & 16.1 & 17.9 & 20.6 & $10.4+0.0387 x$ & 0.79 & $* * * *$ \\
\hline $\mathrm{C}$ & 411 & 403 & 400 & 400 & 401 & $408-0.0354 x$ & 0.29 & $*$ \\
\hline $\mathrm{C}: \mathrm{N}$ ratio & 40.5 & 31.5 & 24.8 & 23.2 & 19.7 & $38.0-0.0745 x$ & 0.80 & $* * * *$ \\
\hline Fruit $\mathrm{N}$ & 16.6 & 18.0 & 18.1 & 22.6 & 23.2 & $16.1+0.0263 x$ & 0.60 & $* * * *$ \\
\hline $\mathrm{C}$ & 403 & 387 & 385 & 396 & 398 & $401+0.0208 x-0.00077 x^{2}$ & 0.31 & $*$ \\
\hline Leaf $\mathrm{N}$ & 26.1 & 28.5 & 32.0 & 33.4 & 34.2 & $26.6+0.0313 x$ & 0.60 & ***** \\
\hline $\mathrm{C}$ & 372 & 357 & 379 & 387 & 385 & --- & --- & NS \\
\hline $\mathrm{C}: \mathrm{N}$ ratio & 14.4 & 12.6 & 11.9 & 11.6 & 11.3 & $13.8-0.0107 x$ & 0.37 & $*$ \\
\hline Stem N & 11.4 & 13.6 & 18.6 & 18.4 & 20.0 & $12.1+0.0321 \mathrm{x}$ & 0.58 & $* * * *$ \\
\hline $\mathrm{C}$ & 400 & 399 & 399 & 407 & 405 & --- & --- & NS \\
\hline $\mathrm{C}: \mathrm{N}$ ratio & 35.2 & 29.6 & 22.5 & 22.6 & 20.6 & $33.3-0.0537 x$ & 0.64 & $* * * *$ \\
\hline Root N & 15.8 & 15.6 & 18.5 & 19.3 & 19.0 & $15.7+0.0147 \mathrm{x}$ & 0.32 & $* *$ \\
\hline $\mathrm{C}$ & 391 & 397 & 399 & 393 & 403 & --- & --- & NS \\
\hline $\mathrm{C}: \mathrm{N}$ ratio & 25.1 & 25.6 & 22.0 & 20.4 & 21.5 & $25.4-0.0182 x$ & 0.28 & $*$ \\
\hline Plant N & 17.6 & 19.4 & 23.8 & 24.2 & 25.7 & $17.9+0.0315 x$ & 0.60 & $* * * *$ \\
\hline $\mathrm{C}$ & 388 & 384 & 391 & 397 & 396 & $385+0.0447 x$ & 0.20 & $*$ \\
\hline $\mathrm{C}: \mathrm{N}$ ratio & 22.3 & 19.9 & 16.7 & 16.5 & 15.6 & $21.6-0.0250 \mathrm{x}$ & 0.57 & $* * * *$ \\
\hline Fruit N & 21.1 & 22.0 & 22.7 & 24.7 & 26.0 & $20.8+0.0185 x$ & 0.37 & $* *$ \\
\hline
\end{tabular}

${ }^{\mathrm{z}}$ All variables reported on the basis of dry weight.

Ns, ***,*****N Nonsignificant or significant at $P<0.05,0.01$, or 0.0001 , respectively. 
not statistically significant. The concentrations of $\operatorname{root} \mathrm{N}$ and $\operatorname{root} \mathrm{C}$ were not affected by $\mathrm{N}$ fertilization in the spring, although root $\mathrm{N}$ increased in the fall with increasing rate of $\mathrm{N}$ fertilization. The concentration of fruit $\mathrm{N}$ increased with the rate of $\mathrm{N}$ fertilization in both spring and fall experiments. The concentration of plant and total $\mathrm{N}$ increased up to 2-fold with $\mathrm{N}$ fertilization, although $\mathrm{C}$ was much less affected. The $\mathrm{C}: \mathrm{N}$ ratios of leaves, stems, roots, and fruit decreased linearly with increasing rate of $\mathrm{N}$ fertilization in both spring and fall plantings, because of increases in $\mathrm{N}$. Seventy-eight percent of the variation in plant $\mathrm{C}: \mathrm{N}$ and total $\mathrm{C}: \mathrm{N}$ ratio in the spring was explained by rates of $\mathrm{N}$ fertilization.

Tissue weight and yield of fruit. In the spring study, weights of leaves, stems, and total plant, marketable yield, and total yield were related to $\mathrm{N}$ fertilization in a quadratic manner, with maximum values of all variables observed at 134 or $202 \mathrm{~kg} \cdot \mathrm{ha}^{-1}$ (Table 2). Root weight was not affected by rate of $\mathrm{N}$ fertilization. In the fall study, leaf and plant weight, and total yield were the only dependent variables influenced by the rate of fertilization. Maximum marketable and total yields in the spring study (54 and $75 \mathrm{t} \cdot \mathrm{ha}^{-1}$, respectively) were obtained at a $\mathrm{N}$ rate of $202 \mathrm{~kg} \cdot \mathrm{ha}^{-1}$. Marketable and total yield in the fall study varied from 54 to $59 \mathrm{t} \cdot \mathrm{ha}^{-1}$ and 65 to $70 \mathrm{t} \cdot \mathrm{ha}^{-1}$, respectively, with the application of 67 to 269 $\mathrm{kg} \cdot \mathrm{ha}^{-1} \mathrm{~N}$ (Table 2). These results are consistent with those of Rhoads et al. (1996), who reported maximum yield for a spring crop of tomatoes at $202 \mathrm{~kg} \cdot \mathrm{ha}^{-1} \mathrm{~N}$, while the fall crop did not respond to $\mathrm{N}$ fertilization rates above $67 \mathrm{~kg} \cdot \mathrm{ha}^{-1}$. There were quadratic relationships for the ratios of marketable yield to plant weight and total yield divided by plant weight (indications of partitioning to reproductive vs. vegetative tissue) for the spring study, with maximum values at $202 \mathrm{~kg} \cdot \mathrm{ha}^{-1} \mathrm{~N}$; in the fall study, these values did not vary significantly with rate of $\mathrm{N}$ fertilization. After factoring in a $4.9 \%$ dry-weight to fresh-weight ratio for fruit, the ratio of total reproductive to vegetative growth ranged from 0.83 to 1.30 in the spring, and from 1.06 to 1.27 in the fall.

Partitioning of $N$ and $C$. In the spring experiment, the quantity of $\mathrm{N}$ partitioned to leaves increased almost 6-fold as the amount of $\mathrm{N}$ applied increased from 0 to $269 \mathrm{~kg} \cdot \mathrm{ha}^{-1}$, yet stem, plant, and total $\mathrm{N}$ increased only 3fold (Table 3 ). The $\mathrm{N}$ partitioned on the fruit was related to $\mathrm{N}$ fertilization in a curvilinear manner, whereas that partitioned to other plant parts (except root $\mathrm{N}$ during the spring) was linearly related to rate of $\mathrm{N}$ fertilization. Although total-N was highest for the $269 \mathrm{~kg} \cdot \mathrm{ha}^{-1}$ treatment, the quantity of $\mathrm{N}$ partitioned to the fruit was greatest for the $202 \mathrm{~kg} \cdot \mathrm{ha}^{-1}$ treatment. In the fall study, the quantity of $\mathrm{N}$ in leaves and fruit was correlated with the rate of $\mathrm{N}$ fertilization in a linear manner, whereas a quadratic relationship best explained stem and plant $\mathrm{N}$. Total $\mathrm{N}$ was linearly related to $\mathrm{N}$ fertilization in both studies. These data support the data of Terman and Brown (1968), who reported that total $\mathrm{N}$ uptake was essentially linear over a broad range of applied N. Data from the spring experiment also appear to support the results of Stark et al. (1983), who found that applying more $\mathrm{N}$ to the soil increased the amount of $\mathrm{N}$ taken up by the plant, although it did not necessarily increase the amount of $\mathrm{N}$ partitioned to the fruit.

When all data were analyzed collectively, the quantity of $\mathrm{N}$ and $\mathrm{C}$ in the fruit paralleled that contained in the plant (Table 3). For example, for all treatments the $\mathrm{N}$ in the plant was $65 \%$ to $102 \%$ of that contained in the fruit. Similarly, C in the plant varied from $74 \%$ to $122 \%$ of that contained in the fruit. The ratios of marketable yield/plant weight and total yield/plant weight were higher in the fall than in the spring. In the spring, the highest ratio of reproductive to vegetative growth occurred at $202 \mathrm{~kg} \cdot \mathrm{ha}^{-1} \mathrm{~N}$; in the fall study, neither marketable yield/plant weight or total yield/plant weight were affected by the rate of $\mathrm{N}$ fertilization. The ratio of total yield to plant weight was fairly constant (Table 2). For example, total yield/plant weight varied from 216 to 286 for both experiments, with the exception of the $0 \mathrm{~kg} \cdot \mathrm{ha}^{-1}$ treatment in the spring study. Given the close correlation of plant $\mathrm{N}$ and crop $\mathrm{N}$, and that of plant $\mathrm{C}$ and crop $\mathrm{C}$ for all treatments in both years, the amount of $\mathrm{N}$ and $\mathrm{C}$ in a tomato crop appears to be influenced or regulated by the quantities of $\mathrm{N}$ and $\mathrm{C}$ in the plant within roughly defined limits.

Soil nitrate- $N$. In the fall, but not the spring experiment, residual soil nitrate- $\mathrm{N}$ increased significantly as a function of rate of $\mathrm{N}$ fertilization. The amount of residual soil nitrate-N (just after final harvest) varied from 7 to 17 $\mathrm{kg} \cdot \mathrm{ha}^{-1}$ in the spring study and 9 to $51 \mathrm{~kg} \cdot \mathrm{ha}^{-1}$

Table 2. Effects of rate of $\mathrm{N}$ fertilization on leaf, stem, root, and plant dry weight, marketable yield $\left(\mathrm{kg} \cdot \mathrm{ha}^{-1}\right)$, total yield, and the ratio of these variables divided by plant weight for two cultivars of tomato planted 29 Mar. 1996 and 31 July 1997.

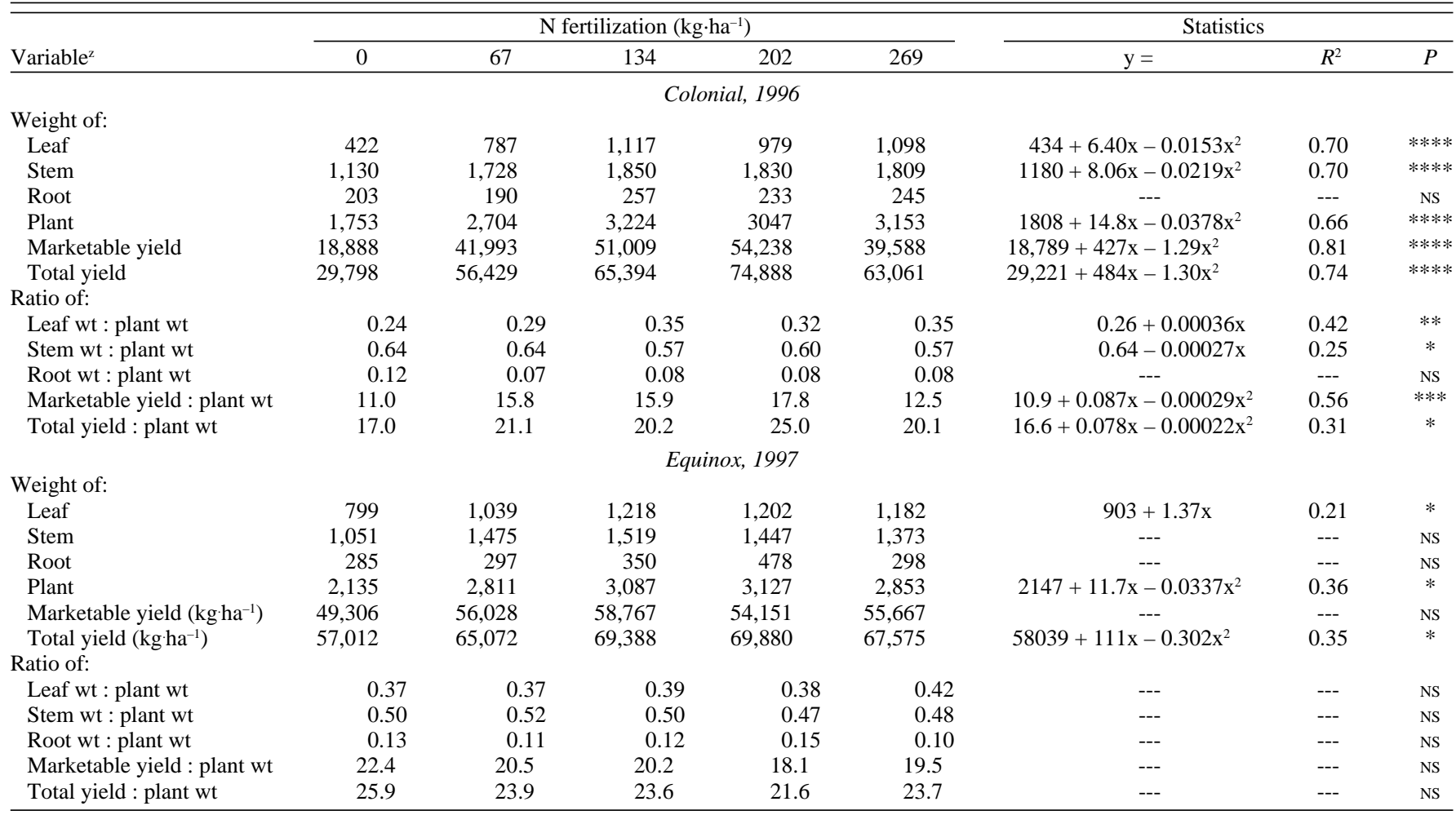

${ }^{\mathrm{z}}$ All variables of plant weight with the exception of marketable and total yield are reported as dry weight; marketable and total yield are fresh weight. To calculate dry weight of marketable and total yield, multiply by 0.049 .

Ns, ${ }^{* * *, * * *, * * * * *}$ Nonsignificant or significant at $P<0.05,0.01,0.001$, or 0.0001 , respectively. 
Table 3. Effects of $\mathrm{N}$ fertilization rate on the quantity of $\mathrm{N}$ and $\mathrm{C}$ partitioned to leaves, stems, roots, plants, fruit, and total (plant + fruit) and on residual nitrate$\mathrm{N}$ in soil after final harvest and $\mathrm{N}$ efficiency [(plant $\mathrm{N}+$ fruit $\mathrm{N}) / \mathrm{kg} \mathrm{N}$ applied] of two cultivars of tomato planted $29 \mathrm{Mar}$. 1996 and 31 July 1997 . All values in $\mathrm{kg} \cdot \mathrm{ha}^{-1}$.

\begin{tabular}{|c|c|c|c|c|c|c|c|c|}
\hline \multirow[b]{2}{*}{ Variable $^{z}$} & \multicolumn{5}{|c|}{$\mathrm{N}$ fertilization $\left(\mathrm{kg} \cdot \mathrm{ha}^{-1}\right)$} & \multicolumn{3}{|c|}{ Statistics } \\
\hline & 0 & 67 & 134 & 202 & 269 & $y=$ & $R^{2}$ & $P$ \\
\hline \multicolumn{9}{|c|}{ Colonial, 1997} \\
\hline \multicolumn{9}{|l|}{$\mathrm{N}$ in: } \\
\hline Leaf & 5.35 & 13.3 & 23.8 & 23.0 & 29.1 & $7.51+0.0847 x$ & 0.80 & $* * * *$ \\
\hline Stem & 9.95 & 19.2 & 24.8 & 27.7 & 33.7 & $11.9+0.0831 x$ & 0.67 & $* * * *$ \\
\hline Root & 2.77 & 2.78 & 3.84 & 3.44 & 3.89 & --- & --- & NS \\
\hline Plant & 18.1 & 35.3 & 52.4 & 54.1 & 66.6 & $22.2+0.172 \mathrm{x}$ & 0.79 & $* * * *$ \\
\hline Fruit & 25.2 & 49.7 & 57.6 & 89.1 & 71.4 & $23.6+0.455 x-0.00096 x^{2}$ & 0.71 & $* * * *$ \\
\hline Total & 43.3 & 85.0 & 110.0 & 143.2 & 138.0 & $54.5+0.368 x$ & 0.79 & $* * * *$ \\
\hline \multicolumn{9}{|l|}{$\mathrm{C}$ in: } \\
\hline Leaf & 164 & 301 & 430 & 366 & 449 & $172+2.23 x-0.00478 x^{2}$ & 0.76 & $* * * *$ \\
\hline Stem & 473 & 696 & 750 & 754 & 752 & $491+3.04 x-0.00789 x^{2}$ & 0.47 & $* *$ \\
\hline Root & 82.4 & 76.4 & 104 & 95.8 & 97.7 & --- & --- & NS \\
\hline Plant & 720 & 1074 & 1284 & 1216 & 1299 & $742+5.4 x-0.0130 x^{2}$ & 0.69 & $* * * *$ \\
\hline Fruit & 589 & 1065 & 1235 & 1558 & 1230 & $573+8.84 x-0.0231 x^{2}$ & 0.73 & $* * * *$ \\
\hline Total & 1309 & 2141 & 2519 & 2670 & 2529 & $1315+14.3 x-0.036 x^{2}$ & 0.78 & $* * * *$ \\
\hline $\begin{array}{l}\text { Residual soil nitrate-N } \\
\qquad\left(\mathrm{kg}^{\left.-h^{-1}\right)}\right.\end{array}$ & 6.86 & 8.76 & 7.62 & 9.14 & 17.1 & --- & --- & NS \\
\hline $\mathrm{N}$ efficiency & --- & 1.27 & 0.82 & 0.71 & 0.51 & $1.42-0.00353 x$ & 0.82 & $* * * *$ \\
\hline \multicolumn{9}{|c|}{ Equinox, 1997} \\
\hline \multicolumn{9}{|l|}{$\mathrm{N}$ in: } \\
\hline Leaf & 21.1 & 29.7 & 39.3 & 40.7 & 40.6 & $24.3+0.0742 x$ & 0.35 & $* *$ \\
\hline Stem & 12.0 & 20.1 & 29.1 & 27.0 & 26.9 & $11.74+0.172 x-0.000434 x^{2}$ & 0.49 & $* *$ \\
\hline Root & 4.58 & 4.71 & 6.63 & 9.36 & 5.57 & --- & --- & NS \\
\hline Plant & 37.7 & 54.6 & 74.9 & 77.0 & 73.1 & $36.2+0.394 x-0.00095 x^{2}$ & 0.48 & $* *$ \\
\hline Fruit & 58.2 & 70.1 & 77.2 & 78.7 & 86.1 & $61.8+0.0927 x$ & 0.45 & $* * *$ \\
\hline Total & 96.2 & 125 & 152 & 156 & 159 & $108+0.224 x$ & 0.45 & $* * *$ \\
\hline \multicolumn{9}{|l|}{$\mathrm{C}$ in: } \\
\hline Leaf & 298 & 365 & 463 & 465 & 455 & $327+0.614 x$ & 0.28 & $*$ \\
\hline Stem & 420 & 589 & 606 & 589 & 556 & $435.3+2.27 x-0.0069 x^{2}$ & 0.30 & $*$ \\
\hline Root & 111 & 118 & 140 & 188 & 120 & --- & --- & NS \\
\hline Plant & 829 & 1073 & 1209 & 1242 & 1131 & $826+4.60 x-0.0128 x^{2}$ & 0.39 & $*$ \\
\hline Fruit & 1122 & 1274 & 1346 & 1253 & 1316 & --- & --- & NS \\
\hline Total & 1975 & 2347 & 2555 & 2495 & 2446 & $1991+6.30 x-0.0174 x^{2}$ & 0.39 & $*$ \\
\hline $\begin{array}{l}\text { Residual soil nitrate-N } \\
\quad\left(\mathrm{kg} \mathrm{ha}^{-1}\right)\end{array}$ & 8.50 & 9.50 & 22.1 & 21.3 & 50.6 & $3.63+0.141 x$ & 0.51 & $* * *$ \\
\hline $\mathrm{N}$ efficiency & --- & 1.86 & 1.14 & 0.77 & 0.59 & $2.13-0.00620 x$ & 0.81 & $* * * *$ \\
\hline
\end{tabular}

${ }^{\mathrm{z}}$ All plant variables are reported on the basis of dry weight.

ns, ${ }^{*},{ }^{* *}, *^{* * *},{ }^{* * * * *}$ Nonsignificant or significant at $P<0.05,0.01,0.001$, or 0.0001 , respectively.

in the fall study. Soil nitrate-N was substantially higher in the $269 \mathrm{~kg} \cdot \mathrm{ha}^{-1}$ treatment, which suggests an increased level of nitrate leaching at this high level of $\mathrm{N}$ fertilization.

Crop residues are also a significant source of $\mathrm{N}$ and may contribute greatly to soil nitrate$\mathrm{N}$. For example, foliage of sugar beets contains 50 to $150 \mathrm{~kg} \cdot \mathrm{ha}^{-1} \mathrm{~N}$ (Neeteson and Ehlert, 1989; Wehrmann and Scharpf, 1989). The quantity of $\mathrm{N}$ in tomato plants after final harvest varied between 52 and $77 \mathrm{~kg} \cdot \mathrm{ha}^{-1}$ for the preplant $\mathrm{N}$ rates of 134 to $269 \mathrm{~kg} \cdot \mathrm{ha}^{-1}$ (Table 3 ). However, when grown in plastic mulch, only root systems (a small proportion of plant biomass; Table 2) are immediately reincorporated back into the soil. Traditionally, postharvest treatment of tomato fields includes the removal of mulch, the application of herbicide (1,1'-dimethyl-4,4'-bipyridinium chloride), burning of string (and some plant material), and the recovery of the stakes. Thus, the amount of aboveground biomass that is reincorporporated back into the soil is only a small percentage of that existing in the fresh plant.

We conclude that soil-N was more limiting in the spring than in the fall. Plant N varied 3.7fold among $\mathrm{N}$ treatments in the spring crop and 1.9 -fold in the fall crop, and total $N$ varied $\approx 3$ - fold among $\mathrm{N}$ treatments in the spring study, but only 1.5 -fold in the fall study (Table 3 ). Total $\mathrm{N}$ content of plants in the $0 \mathrm{~kg} \cdot \mathrm{ha}^{-1}$ treatment in the spring was about one-half that of similarly treated plants in the fall, and fewer significant trends occurred in the fall as a function of $\mathrm{N}$ fertilization. In addition, residual soil nitrate- $\mathrm{N}$ was substantially higher in the fall than in the spring. However, one cannot conclude that the stronger influence of preplant $\mathrm{N}$ in the spring than in the fall experiment was related to environmental factors, since the cultivars also differed.

In general, quadratic functions best explained the partitioning of $\mathrm{C}$ among leaf, stem, plant, fruit, and total plant plus fruit as a function of the rate of $\mathrm{N}$ fertilization, with most variables approaching a maximum at $134 \mathrm{~kg} \cdot \mathrm{ha}^{-1}$. As might be expected, the quantity of $\mathrm{C}$ contained in the various plant fractions mirrored trends in plant weight (Table 2) since $\mathrm{C}$ is a major contributor to weight. Although plant $\mathrm{C}$ and plant weight did not increase when the application of preplant $\mathrm{N}$ exceeded $134 \mathrm{~kg} \cdot \mathrm{ha}^{-1}$, yield was greatest with $202 \mathrm{~kg} \cdot \mathrm{ha}^{-1}$.

Efficiency of $\mathrm{N}$, defined as the ratio of $\mathrm{N}$ in plant plus fruit to that applied as fertilizer, was inversely related to rate of fertilization, and varied 2.5- and 3.2-fold among treatments in the spring and fall, respectively. Only plants with the $67 \mathrm{~kg} \cdot \mathrm{ha}^{-1}$ treatment (spring) and with the 67 and $134 \mathrm{~kg} \cdot \mathrm{ha}^{-1}$ treatments (fall) removed more $\mathrm{N}$ (plant plus crop) than was applied. (Division by zero precluded an assessment of the $0 \mathrm{~kg} \cdot \mathrm{ha}^{-1}$ treatment.) The total amount of $\mathrm{N}$ removed from the soil by a tomato crop appears to be largely independent of the amount applied, as Stark et al. (1983) showed that an increase in $\mathrm{N}$ application rate from 120 to $585 \mathrm{~kg} \cdot \mathrm{ha}^{-1}$ only slightly increased (by $40 \mathrm{~kg} \cdot \mathrm{ha}^{-1}$ ) the amount of $\mathrm{N}$ harvested in the crop. However, our study supports the observations of Stark et al. (1983), in that increasing $\mathrm{N}$ fertilization increased the amount of $\mathrm{N}$ partitioned to vegetative portions of the plant.

In conclusion, in both spring ('Colonial') and fall ('Equinox') experiments, the concentration of $\mathrm{N}$ and the total $\mathrm{N}$ taken up by the plant increased linearly with an increasing rate of $\mathrm{N}$ fertilization, while the concentration of $\mathrm{C}$ (spring only), total plant $\mathrm{C}$, plant biomass, and total fruit yield increased with $\mathrm{N}$ fertilization in a quadratic manner (maximum at 134 or 202 $\mathrm{kg} \cdot \mathrm{ha}^{-1}$ ). The $\mathrm{C}: \mathrm{N}$ ratio of leaves, stems, roots, entire plants, fruit, and total plants plus fruit decreased with increasing preplant $\mathrm{N}$ as a 
result of the strong influence of fertilization on $\mathrm{N}$ concentration. Considering all treatments for both spring ('Colonial') and fall ('Equinox') crops, the quantity of $\mathrm{N}$ and $\mathrm{C}$ partitioned among vegetative and fruit tissues was closely related, suggesting that the amount of $\mathrm{N}$ and $\mathrm{C}$ in the crop is dependent on the pool of $\mathrm{N}$ and $\mathrm{C}$ in the plant. The highest rate of $\mathrm{N}$ fertilization $\left(269 \mathrm{~kg} \cdot \mathrm{ha}^{-1}\right)$ resulted in the lowest $\mathrm{N}$ efficiency and the highest amount of residual soil nitrate- $\mathrm{N}$.

\section{Literature Cited}

Angus, J.F. 1995. Modeling N fertilization requirements for crops and pastures, p. 109-127. In: P.E. Bacon (ed.). Nitrogen fertilization in the environment. Marcel Dekker, New York.

De Willigen, P., W.P. Wadman, and M. Van Noordwijk. 1992. Model calculations of the risks of accumulation of soil mineral nitrogen in autumn after arable crops and field vegetables, p. 87-101. In: H.G. Van der Meer and J.H.H. Spiertz (eds.). Stikstofstromen in Agroecosystemen. Agrobiologische Thema's 6. DLOCentre for Agrobiolog. Res., Wageningen.

Drinkwater, L.E., D.K. Letourneau, F. Workneh, A.H.C. van Bruggen, and C. Shennan. 1995.
Fundamental differences between conventional and organic tomato agroecosystems in California. Ecol. Applicat. 5(4):1098-1112.

Everett, P.H. 1976. Effect of nitrogen and potassium on fruit yield and size of mulch-grown staked tomatoes. Proc. Fla. State Hort. Soc. 89:159 162.

Hanlon, E.A., J. Gonzalaez, and J.M. Bartos. 1994 Extension Soil Testing Laboratory procedures and training manual. Florida Coop. Ext. Serv., IFAS, Univ. of Florida, Gainesville. Circ. 812.

Hochmuth, G.J. and E.A. Hanlon. 1995. Commercial vegetable crop nutrient requirements in Florida. Florida Coop. Ext. Serv. SP-177.

Hochmuth, G.J., D. Maynard, C. Vavrina, and E.A. Hanlon. 1991. Plant tissue analysis and interpretation for vegetable crops in Florida. Florida Coop. Ext. Serv. Spec. Ser. SS-VEC-42.

Hochmuth, G.J. and D.M. Maynard. 1996. Vegetable production guide for Florida. Univ. of Florida, Florida Coop. Ext. Serv. SP-170.

Locascio, S.J., G.J. Hochmuth, F.M. Rhoads, S.M Olson, A.G. Smajstrla, and E.A. Hanlon. 1997. Nitrogen and potassium application scheduling effects on drip-irrigated tomato yield and leaf tissue analysis. HortScience 32:230-235.

Neeteson, J.J. 1995. Nitrogen management for intensively grown arable crops and field vegetables, p. 295-325. In: P.E. Bacon (ed.). Nitro- gen fertilization in the environment. Marcel Dekker, New York.

Neeteson, J.J. and P.A.I. Ehlert. 1989. Environmental aspects of applying inorganic fertilizers to sugar beet, p. 79-91. In: Proc. 52nd Winter Congr. Intl. Sugar Beet Res. Inst., Brussels.

Rhoads, F.M., S.M. Olson, G.J. Hochmuth, and E.A. Hanlon. 1996. Yield and petiole-sap nitrate levels of tomato with $\mathrm{N}$ rates applied preplant or fertigated. Proc. Soil and Crop. Sci. Soc. Florida. 55:20-22.

SAS Institute. 1985. SAS/STAT guide for personal computers. Ver. 6 ed. SAS Inst., Cary, N.C.

Stark, J.C., W.M. Jarrell, J. Letey, and N. Valoras. 1983. Nitrogen use efficiency of trickle-irrigated tomatoes receiving continuous injection of N. Agron. J. 75:672-676.

Strong, W.M. 1995. Nitrogen fertilization of upland crops, p. 129-169. In: P.E. Bacon (ed.). Nitrogen fertilization in the environment. Marcel Dekker, New York.

Terman, G.L. and M.A. Brown. 1968. Crop recovery of applied fertilizer nitrogen. Plant Soil 29:48-65.

Wehrmann, J., and H.C. Scharpf. 1989. Reduction of nitrate leaching in a vegetable farm: fertilization, crop rotation, plant residues, p. 147-156 In: J.C. Germon (ed.). Management systems to reduce impact of nitrates. Elsevier, London. 